\title{
molecules
}

ISSN 1420-3049

www.mdpi.com/journal/molecules

Article

\section{Deguelin Inhibits the Migration and Invasion of U-2 OS Human Osteosarcoma Cells via the Inhibition of Matrix Metalloproteinase-2/-9 in Vitro}

\section{Hung-Sheng Shang ${ }^{1}$, Jin-Biou Chang ${ }^{1,2}$, Ju-Hwa Lin ${ }^{3}$, Jing-Pin Lin ${ }^{4}$, Shu-Chun Hsu ${ }^{3}$, Chi-Ming Liu ${ }^{5}$, Jia-You Liu ${ }^{6}$, Ping-Ping Wu ${ }^{7}$, Hsu-Feng Lu ${ }^{6,8}$, Man-Kuan Au ${ }^{9, *}$ and Jing-Gung Chung ${ }^{3,10, *}$}

1 Department of Pathology, National Defense Medical Center, Division of Clinical Pathology, Tri-Service General Hospital, Taipei 114, Taiwan

2 Department of Medical Laboratory Science and Biotechnology, Yuanpei University, Hsinchu 300, Taiwan

3 Department of Biological Science and Technology, China Medical University, No 91, Hsueh-Shih Road, Taichung 404, Taiwan

4 School of Chinese Medicine, China Medical University, Taichung 404, Taiwan

5 Department of Research and Education, Cheng-Hsin General Hospital, No.45, Cheng Hsin St., Pai-Tou, Taipei 112, Taiwan

6 Department of Clinical Pathology, Cheng-Hsin General Hospital, Taipei 112, Taiwan

7 School of Pharmacy, China Medical University, Taichung 404, Taiwan

8 Department of Restaurant, Hotel and Institutional Management, Fu-Jen Catholic University, New Taipei City 242, Taiwan

9 Department of Orthopedic Surgery, Cheng-Hsin General Hospital, Taipei 112, Taiwan

10 Department of Biotechnology, Asia University, Taichung 413, Taiwan

* Authors to whom correspondence should be addressed; E-Mails: ch6200@chgh.org.tw (M.-K.A.); jgchung@mail.cmu.edu.tw (J.-G.C.); Tel.: +886-228-264-400 (ext. 5850) (M.-K.A.); +886-4-2205-3366 (ext. 8000) (J.-G.C.); Fax: +886-228-264-517 (M.-K.A.); $+886-4-2205-3764$ (J.-G.C.).

External Editor: Derek J. McPhee

Received: 15 August 2014; in revised form: 16 September 2014 / Accepted: 23 September 2014 / Published: 15 October 2014

Abstract: Osteosarcoma is the most common malignant primary bone tumor in children and young adults and lung metastasis is the main cause of death in those patients. 
Deguelin, a naturally occurring rotenoid, is known to be an Akt inhibitor and to exhibit cytotoxic effects, including antiproliferative and anticarcinogenic activities, in several cancers. In the present study, we determined if deguelin would inhibit migration and invasion in U-2 OS human osteosarcoma cells. Deguelin significantly inhibited migration and invasion of U-2 OS human osteosarcoma cells which was associated with a reduction of activities of matrix metalloproteinases-2 (MMP-2) and matrix metalloproteinases-9 (MMP-9). Furthermore, results from western blotting indicated that deguelin decreased the cell proliferation and cell growth-associated protein levels, such as SOS1, PKC, Ras, PI3K, p-AKT(Ser473), IRE-1 $\alpha$, MEKK3, iNOS, COX2, p-ERK1/2, p-JNK1/2, p-p38; the cell motility and focal adhesion-associated protein levels, such as Rho A, FAK, ROCK-1; the invasion-associated protein levels, such as TIMP1, uPA, MMP-2. MMP-9, MMP-13, MMP-1 and VEGF in U-2 OS cells. Confocal microscopy revealed that deguelin reduced NF- $\kappa$ B p65, Rho A and ROCK-1 protein levels in cytosol. MMP-7, MMP-9 and Rho A mRNA levels were suppressed by deguelin. These in vitro results provide evidence that deguelin may have potential as a novel anti-cancer agent for the treatment of osteosarcoma and provides the rationale for in vivo studies in animal models.

Keywords: deguelin; U-2 OS human osteosarcoma cells; migration; invasion

\section{Introduction}

Osteosarcoma is the most common malignant bone tumor found in children and adolescents [1-3]. It affects the distal long bones via the formation of neoplastic bone tissue [4]. The main cause of death of osteosarcoma patients is lung metastasis [5,6]. The five-year survival rate of patients with osteosarcoma are no greater than $30 \%$ after the detection of lung metastasis and lung has some of the most common migration tissues for osteosarcoma and this leads to death within 6 months to one year [7]. Currently, conventional treatments such as surgical resection, chemotherapy, and radiation, or combinations of chemotherapy and radiation are not satisfactory. An effective treatment for osteosarcomas is needed.

Cancer cell invasion and metastasis lead to a poor prognosis and are a therapeutic challenge [8]. These cellular processes are complex involving activation/degradation of extra-cellular matrix (ECM) and the break-down of ECM by proteinases [9-12]. Matrix metalloproteinases (MMPs) are a family of ECM degrading proteinases which play an important role in cell invasion and metastasis involving ECM degradation [5,13]. There has been great interest in finding effective MMP inhibitors for the treatment of osteosarcoma [14-16].

Deguelin is a rotenoid, derived from several plant species, including Mondulea sericea. It has been reported to reduce the in vivo incidence of chemically induced-tumors in animal models of lung [17], skin [18] and mammary [18,19] tumors. Deguelin suppressed the formation of cazoxymethane (carcinogen)-induced aberrant crypt foci in mouse colon [20]. Deguelin is a potent inhibitor of ornithine decarboxylase (ODC) activity [21] and it also can trigger inhibition of the PI3K/Akt pathway [22,23] and down-regulation of cyclooxygenase-2 [22]. It was reported that deguelin inhibits the NF- $\mathrm{B}$ 
activation pathway, which may explain its role in the suppression of carcinogenesis and cellular proliferation [24]. Degulin had been reported to affect different types of human cancer cells but there is no available information on its effects on migration and invasion. In the present study, we investigated the effects of deguelin on the migration and invasion in human bone cancer U-2 OS cells. Deguelin inhibited the migration and invasion of U-2 OS cells by down regulation of MMP-2 and -9.

\section{Results and Discussion}

\subsection{Deguelin Reduces the Percentage of Viable U2-OS Human Osteosarcoma Cells}

After U-2 OS cells were treated with $0,5,10,15$ and $20 \mu \mathrm{M}$ of deguelin for 24 and $48 \mathrm{~h}$, cells were harvested and the percentage of viable cells were determined. Figure 1 shows that deguelin significantly decreased the percentage of viable cells at 15 and $20 \mu \mathrm{M}$. Deguelin concentrations of 10 and $15 \mu \mathrm{M}$ were used for all experiments.

Figure 1. Deguelin affects the percentage of viable U-2 OS human osteosacroma cells. U2-OS cells $\left(2 \times 10^{5}\right.$ cells/well) were incubated with $0,5,10,15$, and $20 \mu \mathrm{M}$ of deguelin for $24 \mathrm{~h}$ and $48 \mathrm{~h}$. Cell were harvested to determine the percentage of viable cells by flow cytometry as described in the Experimental Section. ${ }^{*} p<0.05, * * * p<0.001$, significant difference between deguelin-treated groups and the control as analyzed by Student's $t$ test.

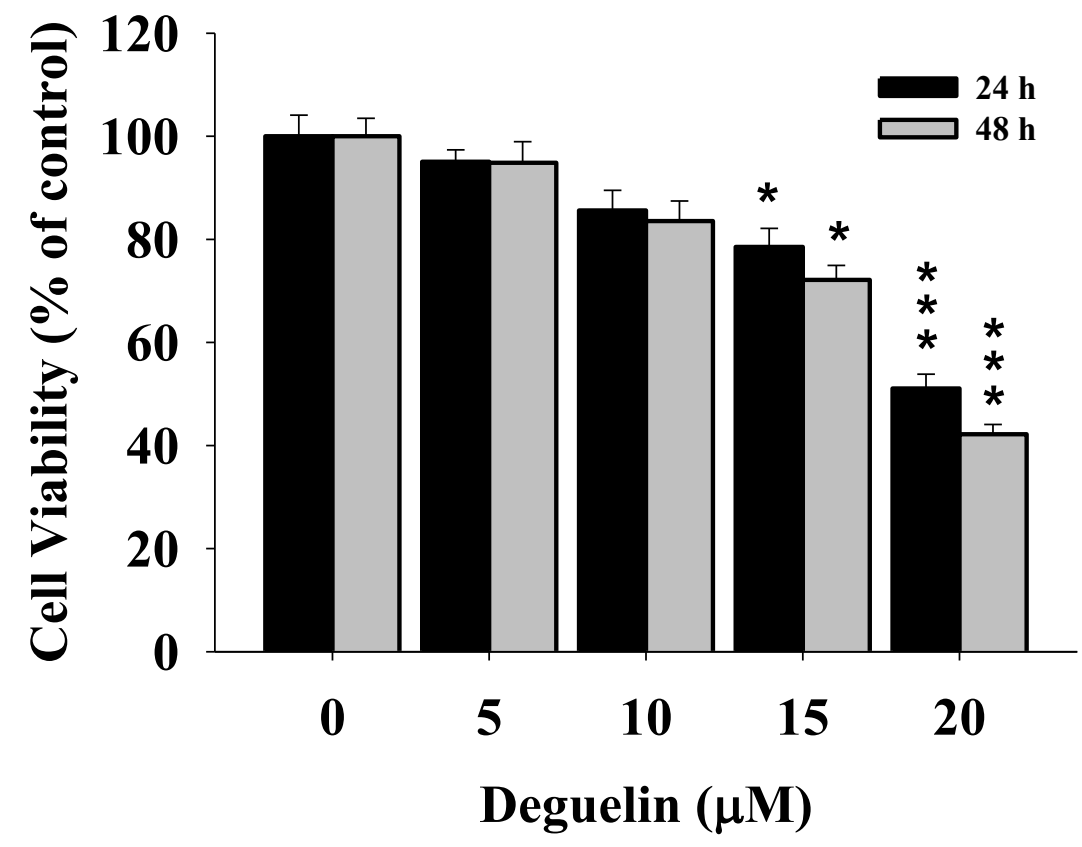

\subsection{Deguelin Suppresses the Migration of U-2 OS Cells in Vitro}

Effects of deguelin on migration and invasion of U-2 OS cells was determined using a wound healing assay. U-2 OS cells were exposed to 0,10 , and $15 \mu \mathrm{M}$ of deguelin, after which, as seen in Figure 2, deguelin inhibited the migration of U-2 OS cells in a dose- and time-dependent manner. 


\subsection{Deguelin Inhibited the Migration and Invasion of U2-OS Cells in Vitro}

In order to confirm the effect of deguelin on migration and invasion of U-2 OS cells, cells were treated with 0,10 and $15 \mu \mathrm{M}$ of deguelin for 24 and $48 \mathrm{~h}$ and seeded on Millicell chambers with uncoated (for migration) or matrigel-coated (for invasion) filters.

Figure 2. Deguelin affecting the migration of U-2 OS cells examined by wound healing assay. Cells $\left(2 \times 10^{5}\right.$ cells/well $)$ were placed on the dish for $24 \mathrm{~h}$ before a wound was produced by scraping confluent cell layers with a pipette tip. Deguelin was added to the well at the final concentration $(0,10$ and $15 \mu \mathrm{M})$ then incubation for 0,12 and $24 \mathrm{~h}(\mathbf{A})$. Some representative photographs of migrating treated and untreated cells are presented. The migrated cells in the five random fields after exposure for $0,12,24 \mathrm{~h}$ were counted to quantify, and data was expressed as mean \pm S.D. $* * * p<0.001$ significant difference between deguelin-treated groups and the untreated groups as analyzed by Student's $t$ test (B).

$\mathbf{0 ~ h}$
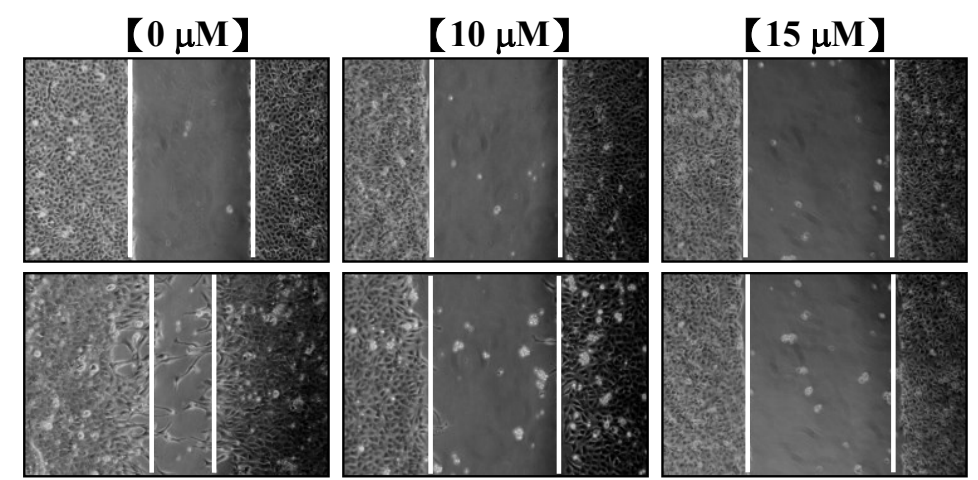

$24 \mathrm{~h}$
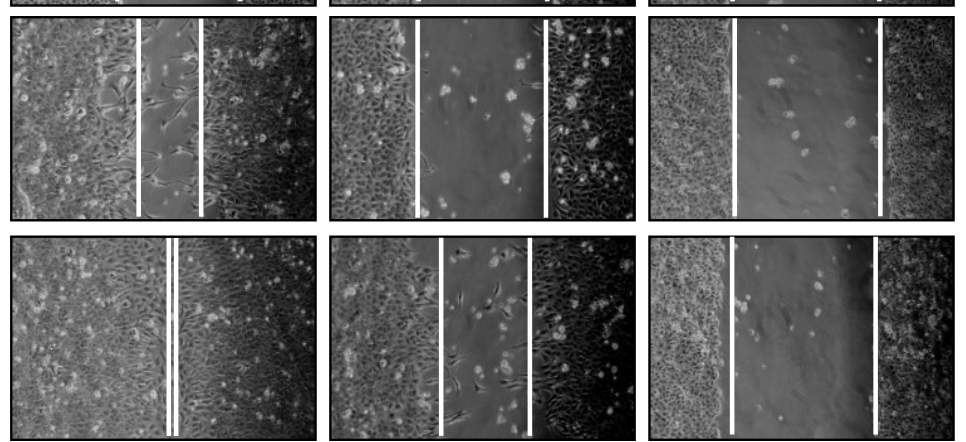

(A)

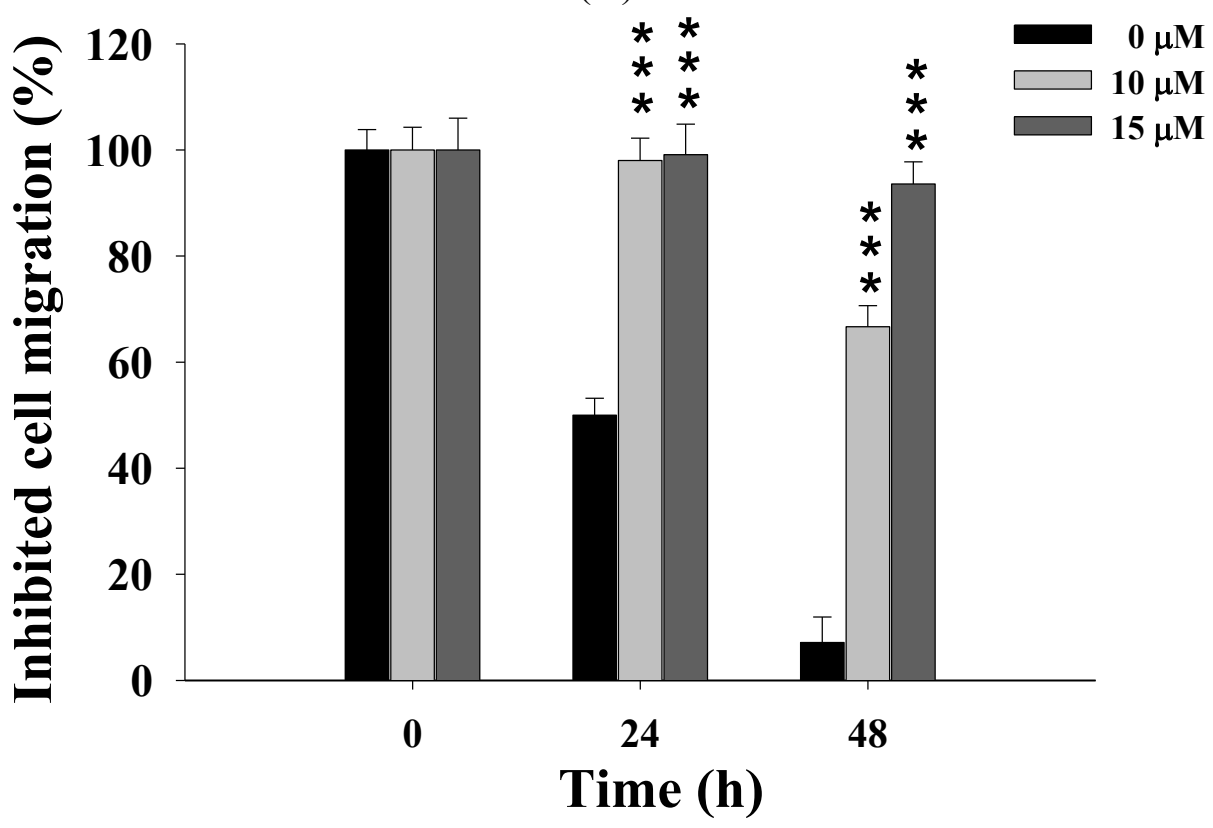

(B) 
At the end of incubation, cell migration activity and invasive potential of U-2 OS cells were measured, photographed and results are shown in Figures 3A,B and 4A,B. Figure 3A,B indicated that deguelin significantly inhibited migration of U-2 OS cells in vitro and this effect was dose-dependent. Figure 4A,B indicated that deguelin significantly inhibited the invasion of U-2 OS cells and these effects were dose-dependent.

Figure 3. Deguelin suppressed the migration of U-2 OS cells in vitro. U-2 OS cells $\left(5 \times 10^{4}\right.$ cells/well) were incubated with 0,10 and $15 \mu \mathrm{M}$ of deguelin for 24 and $48 \mathrm{~h}$ then penetrated through to the lower surface of the filter and were stained with crystal violet and were photographed under a light microscope at $200 \times$. Quantification of cells in the lower chambers was performed by counting cells at $200 \times . * * * p<0.001$ significant difference between deguelin-treated groups and the untreated groups as analyzed by Student's $t$ test. Cells were stained with crystal violet and then were examined and photographed under a light microscope at $200 \times(\mathbf{A})$; The quantification of cells from each treatment in the lower chambers was counted at $200 \times(\mathbf{B})$.

(A)

$24 \mathrm{~h}$
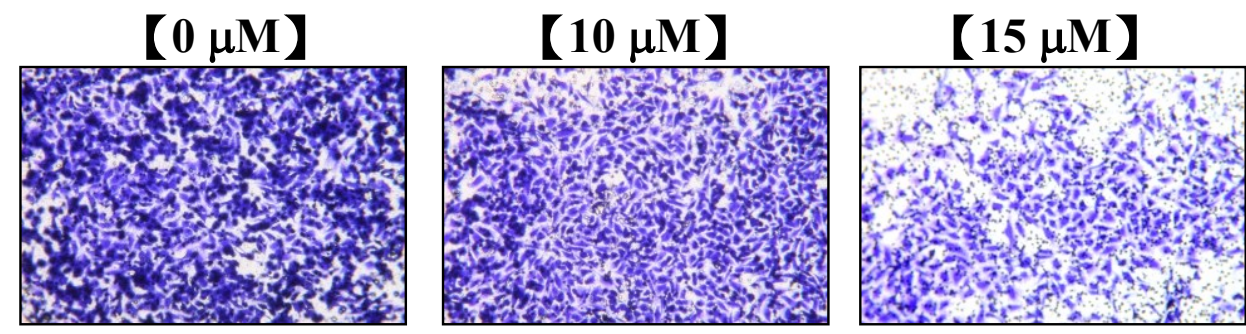

$48 \mathrm{~h}$
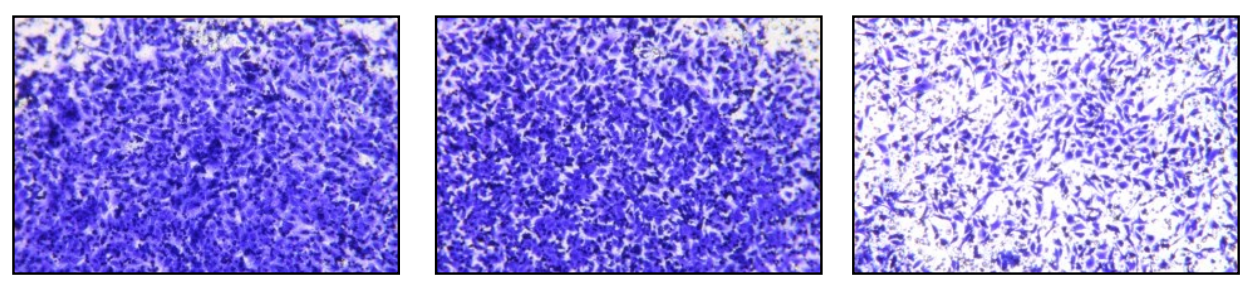

(B)

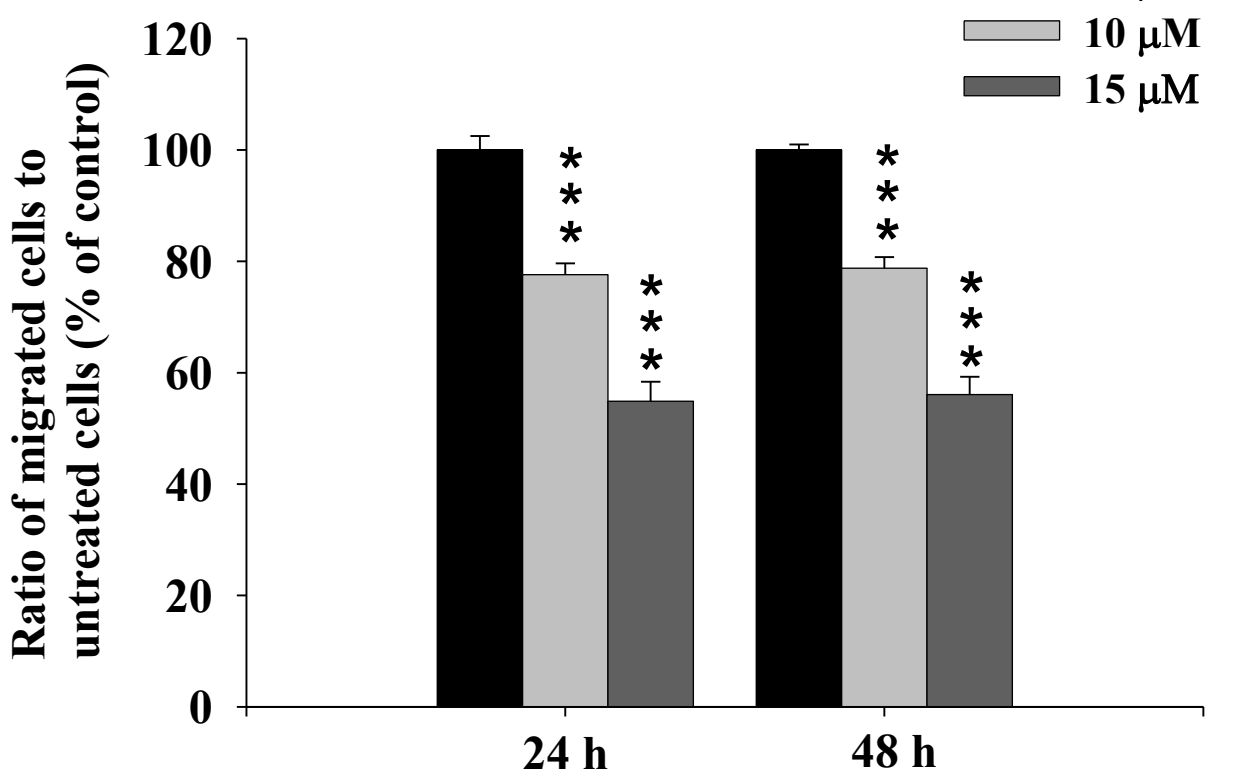


Figure 4. Deguelin suppressed the invasion of U-2 OS cells in vitro. U-2 OS cells $\left(5 \times 10^{4}\right.$ cells/well $)$ were incubated with 0,10 and $15 \mu \mathrm{M}$ of deguelin then penetrated through with the matrigel to the lower surface of the filter were stained with crystal violet and were photographed under a light microscope at $200 \times$. Quantification of cells in the lower chambers was performed by counting cells at 200×. *** $p<0.001$, significant difference between deguelin-treated groups and untreated-groups as analyzed by Student's $t$ test. Cells were stained with crystal violet and then were examined and photographed under a light microscope at $200 \times(\mathbf{A})$; The quantification of cells from each treatment in the lower chambers was counted at $200 \times(\mathbf{B})$.

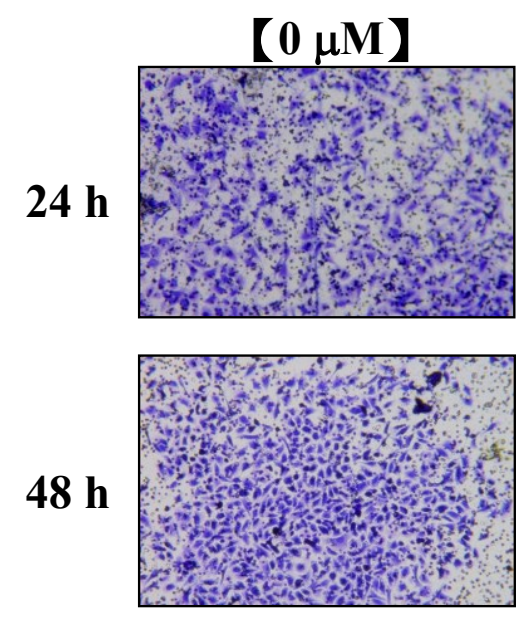

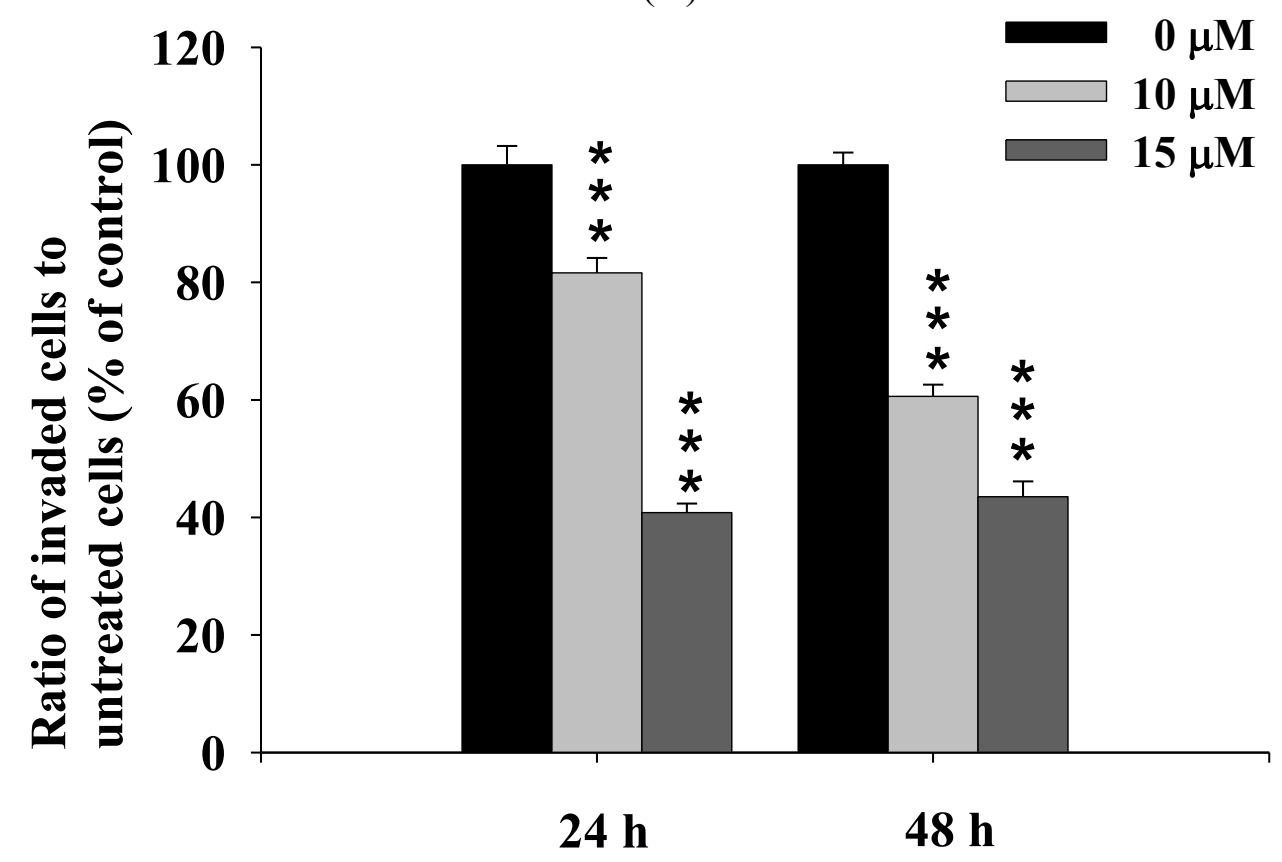
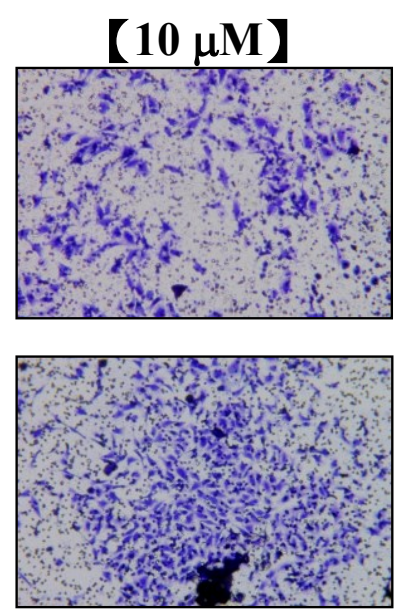

(A)

(B)

\subsection{Deguelin Inhibited the Matrix Metalloproteinases-2 and-9 Activities in U-2 OS Cells}

Gelatin zymography was used to determine if deguelin inhibited migration and invasion was associated with inhibition of MMP-2 and -9 activities and data are presented in Figure 5A,B. Deguelin constitutively decreased MMP-2 and MMP-9 activities in a dose- and time-dependent manner. 
Figure 5. Deguelin affects the activities of MMP-2 and -9 activities in U-2 OS cells. U-2 OS cells $\left(5 \times 10^{4}\right.$ cells/well $)$ were incubated with $0,2.5,5,10,15$ and $20 \mu \mathrm{M}$ of deguelin for 24 (A) and $48 \mathrm{~h}$ (B) then to detect the activity of secreted MMP-2 and MMP-9 using conditioned medium from U-2 OS cells. The different activity of MMP-2 and MMP-9 were determined by densitometric analysis and results are expressed as a percentage of the control (100\%).

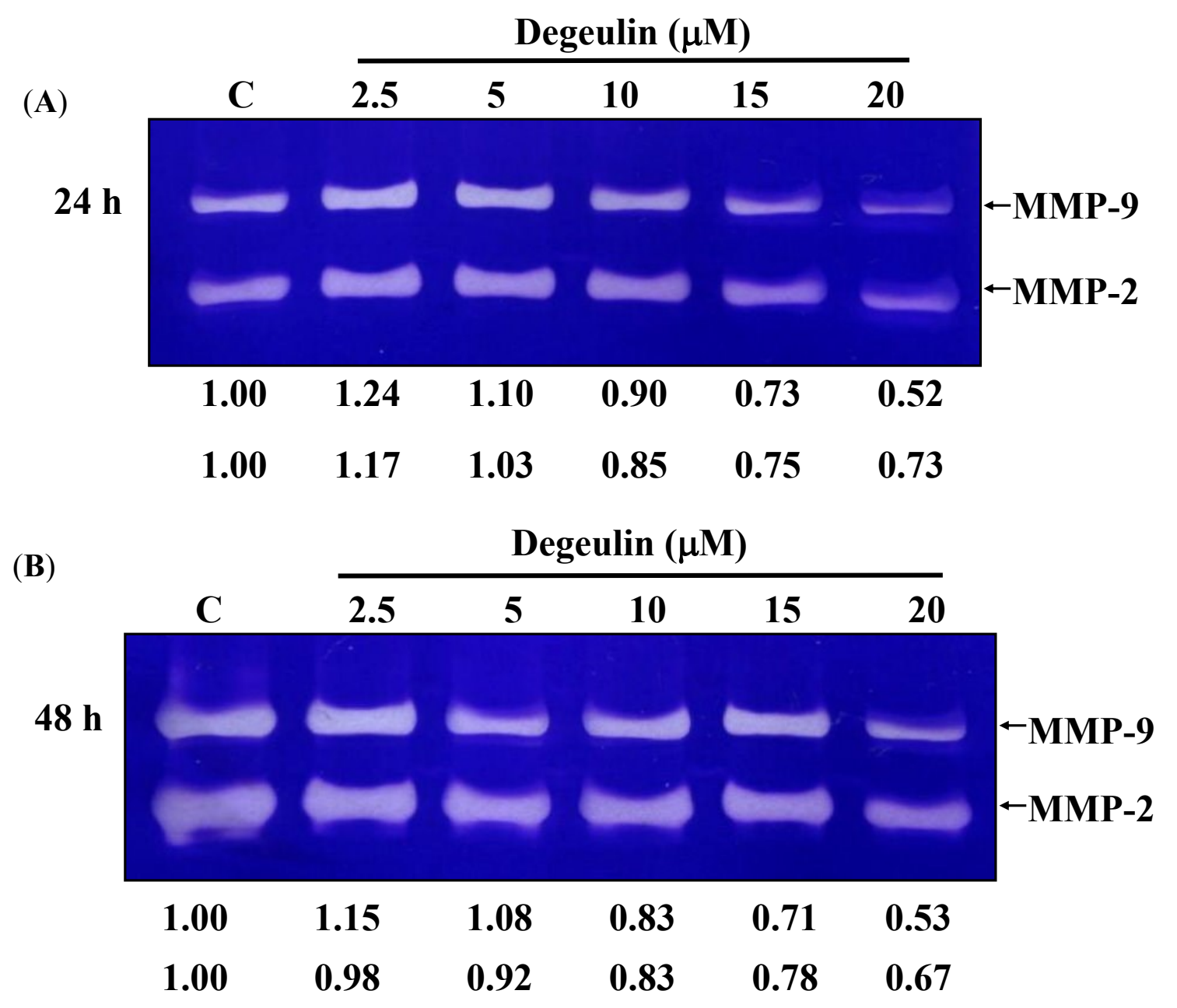

\subsection{Deguelin Alters Levels of Proteins Associated with Migration and Invasion in U-2 OS Cells}

Deguelin effects several signal pathway, such as: cell growth and proliferation associated pathway (Figure 6A), cell motility and focal adhesion associated pathway (Figure 6B), PI3K/AKT/NF-кB pathway (Figure 6C), MAPK pathway (Figure 6D) and invasion associated pathway (Figure 6E,F). Levels of SOS1, GRB2, PKC and Ras (Figure 6A), FAK, Rho A, ROCK-1 and IRE-1 $\alpha$ (Figure 6B), PI3K, p-AKT(Ser473), NF-кB p65, iNOS and COX-2 (Figure 6C), MEKK3, MKK7, p-ERK1/2, p-JNK1/2 and p-p38 (Figure 6D), UPA (Figure 6E), MMP-2, MMP-9, MMP-13, MMP-1 and VEGF (Figure 6F) were lower in deguelin-treated cells than that of control cells. Levels of p-PERK (Figure 6B), p-AKT(Thr308) (Figure 6C), p-c-Jun (Figure 6D), TIMP1 and TIMP2 (Figure 6E) were higher in deguelin-treated cells than that of control cells. GRB2 at $24 \mathrm{~h}$ treatment of deguelin was slightly higher than control but at $48 \mathrm{~h}$ treatment was lower than that of control (Figure 6A). 
Figure 6. Deguelin affect the levels of associated proteins in migration and invasion of U-2 OS cells. U-2 OS cells were treated with deguelin $(0,10,15 \mu \mathrm{M})$ for different periods of time and then cells were collected and the total protein extracts were prepared and determined as described in the Experimental Section. The levels of SOS1, GRB2, PKC and Ras (A), FAK, Rho A, ROCK-1, p-PERK and IRE-1 $\alpha$ (B), PI3K, p-AKT(Thr308), p-AKT(Ser473), NF- $\kappa$ B p65, iNOS and COX-2 (C), MEKK3, MKK7, p-ERK1/2, p-JNK1/2, p-p38 and p-c-JUN (D), TIMP1, TIMP2, UPA (E), MMP-2, MMP-9, MMP-13, MMP-1 and VEGF (F) expressions were estimated by western blotting as described in the Experimental Section.

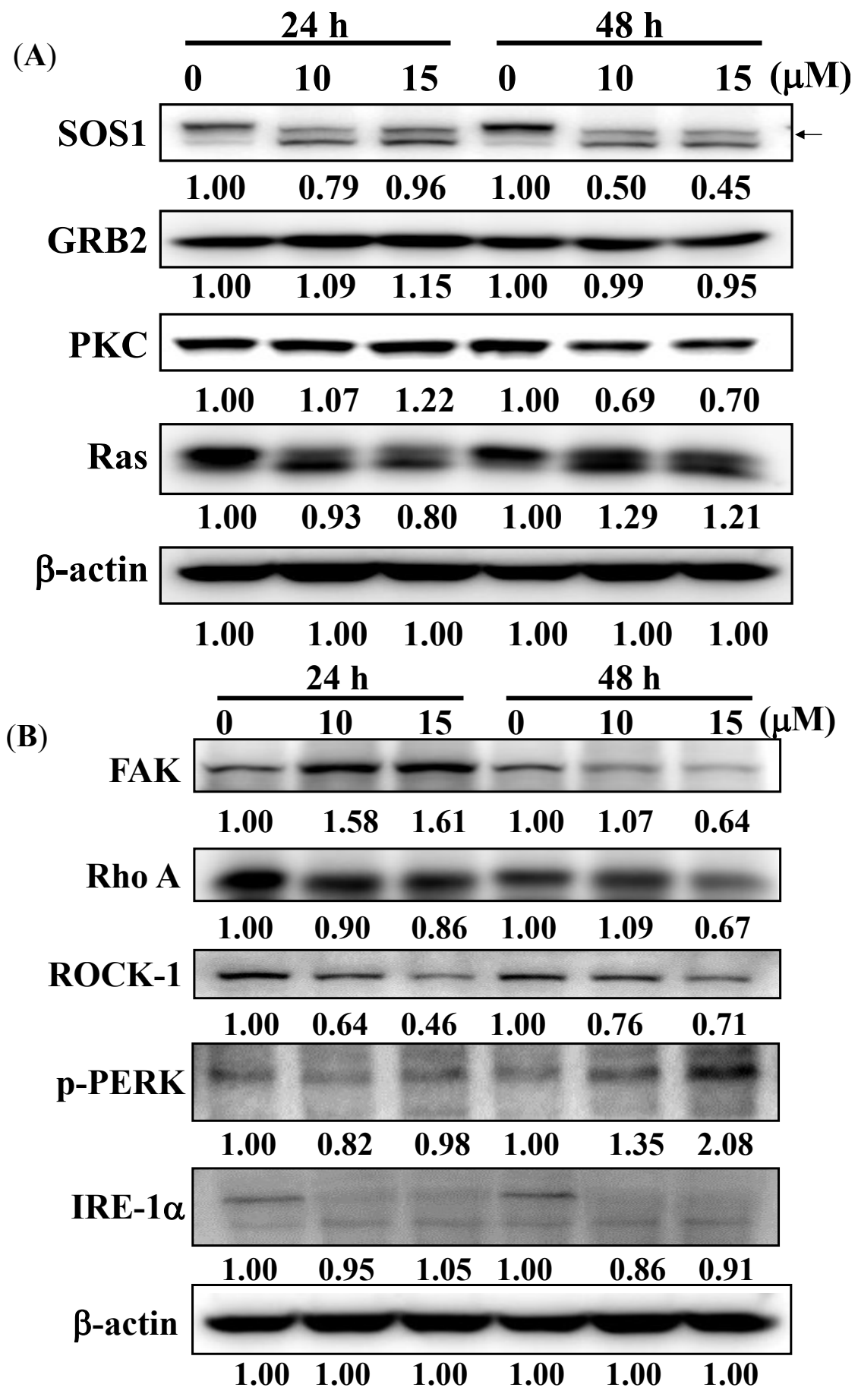


Figure 6. Cont.

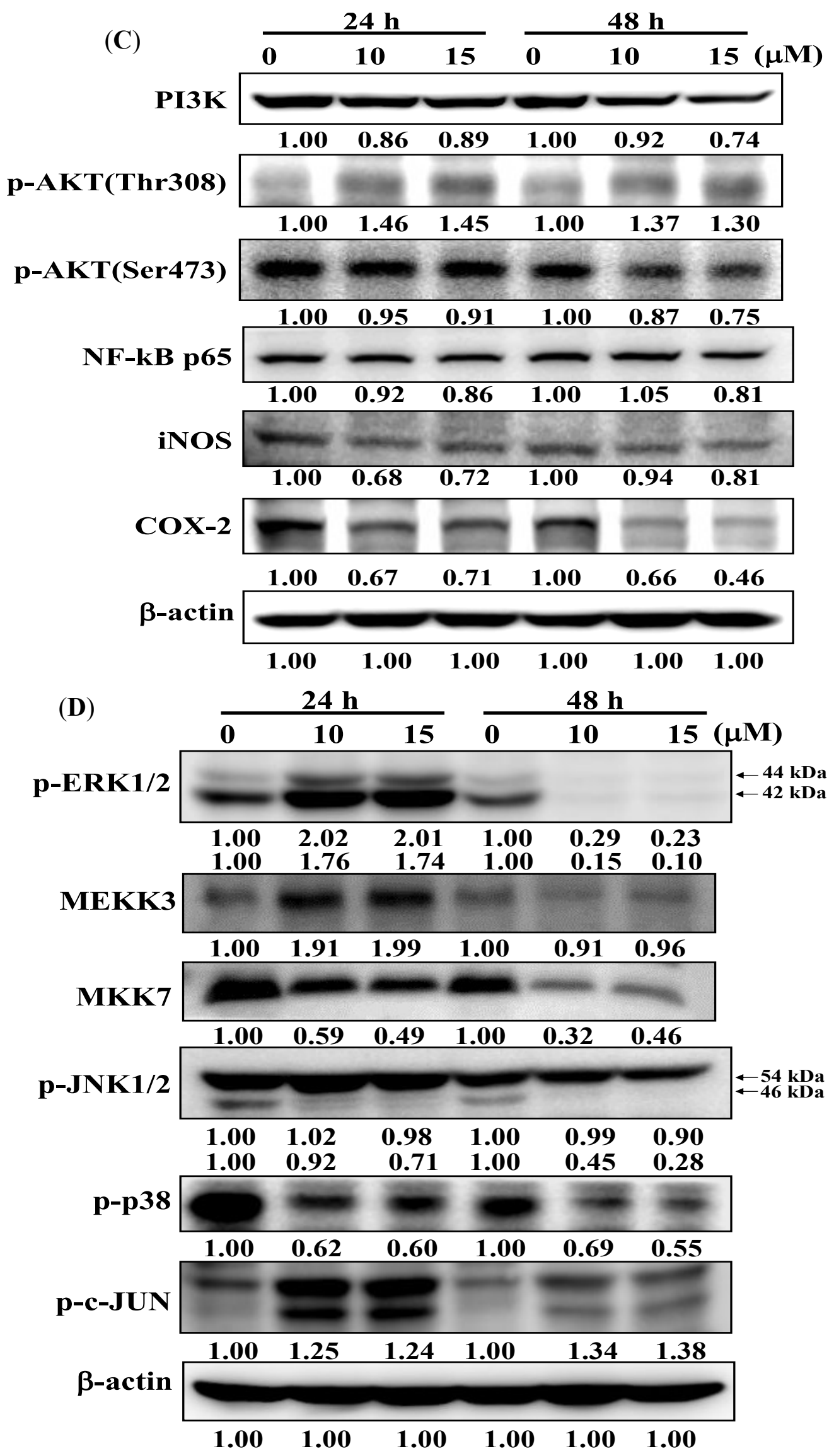


Figure 6. Cont.

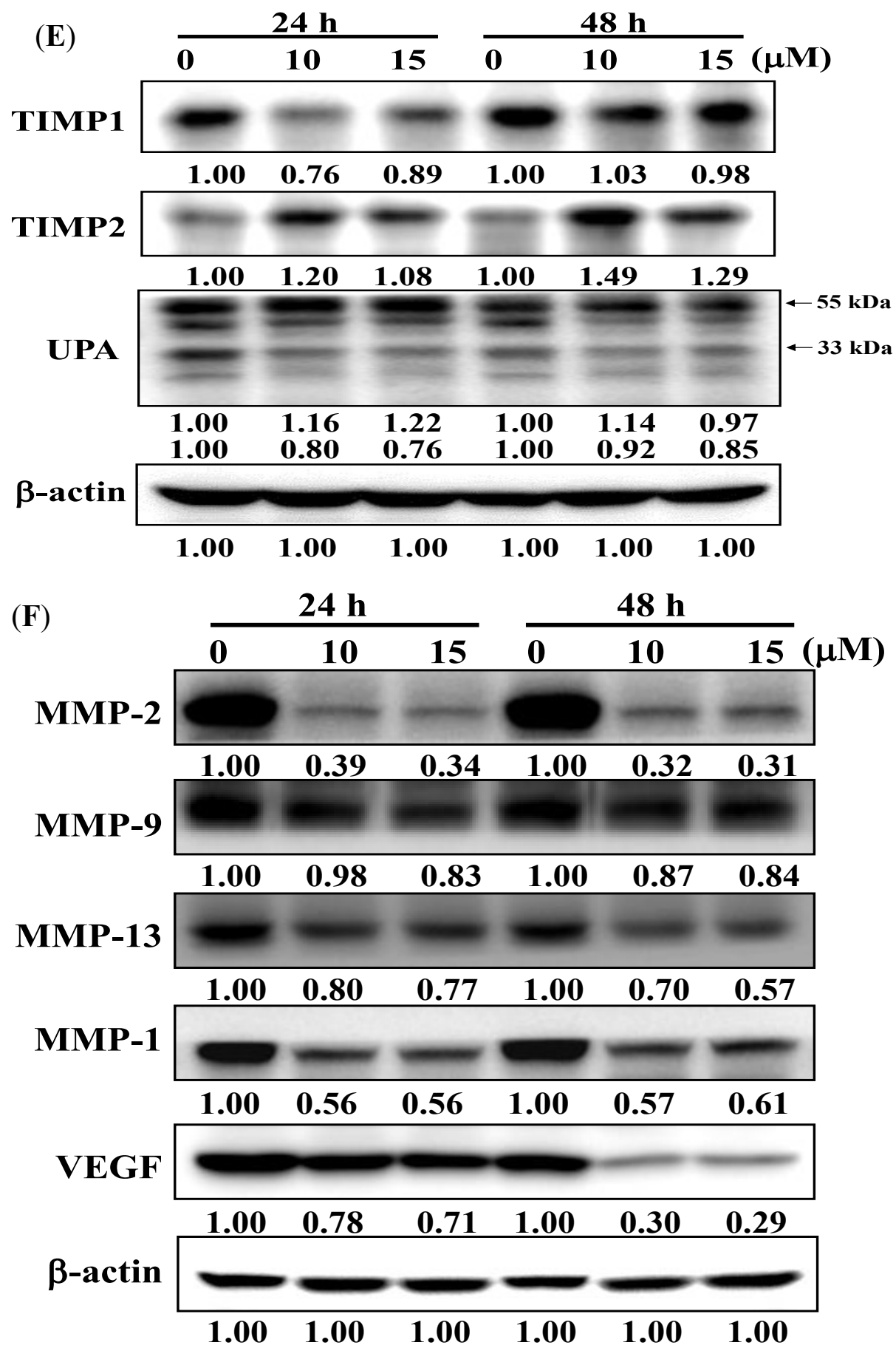

\subsection{Effects of Deguelin on Protein Translocation}

Expression levels of NF- $\kappa \mathrm{B}$ p65, Rho A and ROCK-1 in U-2 OS cells were examined by immuno-staining and the results are shown in Figure 7A-C. Deguelin reduced cytosolic protein levels of NF-кB p65 (Figure 7A), Rho A (Figure 7B) and ROCK-1 (Figure 7C). 
Figure 7. Deguelin affects the NF-кB p65, Rho A and ROCK-1 expression in U-2 OS cells. Cells placed on 6-well chamber slides were treated with $10,15 \mu \mathrm{M}$ of deguelin for $24 \mathrm{~h}$, fixed and stained using anti-NF-kB p65 (A), Rho A (B) and ROCK-1 (C) antibodies (1:200) overnight and then stained with a secondary antibody (FITC-conjugated goat anti-mouse IgG at 1:200 dilution) (green fluorescence) followed by nuclear counterstaining individually performed with PI (red fluorescence). Photomicrographs were obtained using a Leica TCS SP2 confocal spectral microscope as described in the Experimental Section.

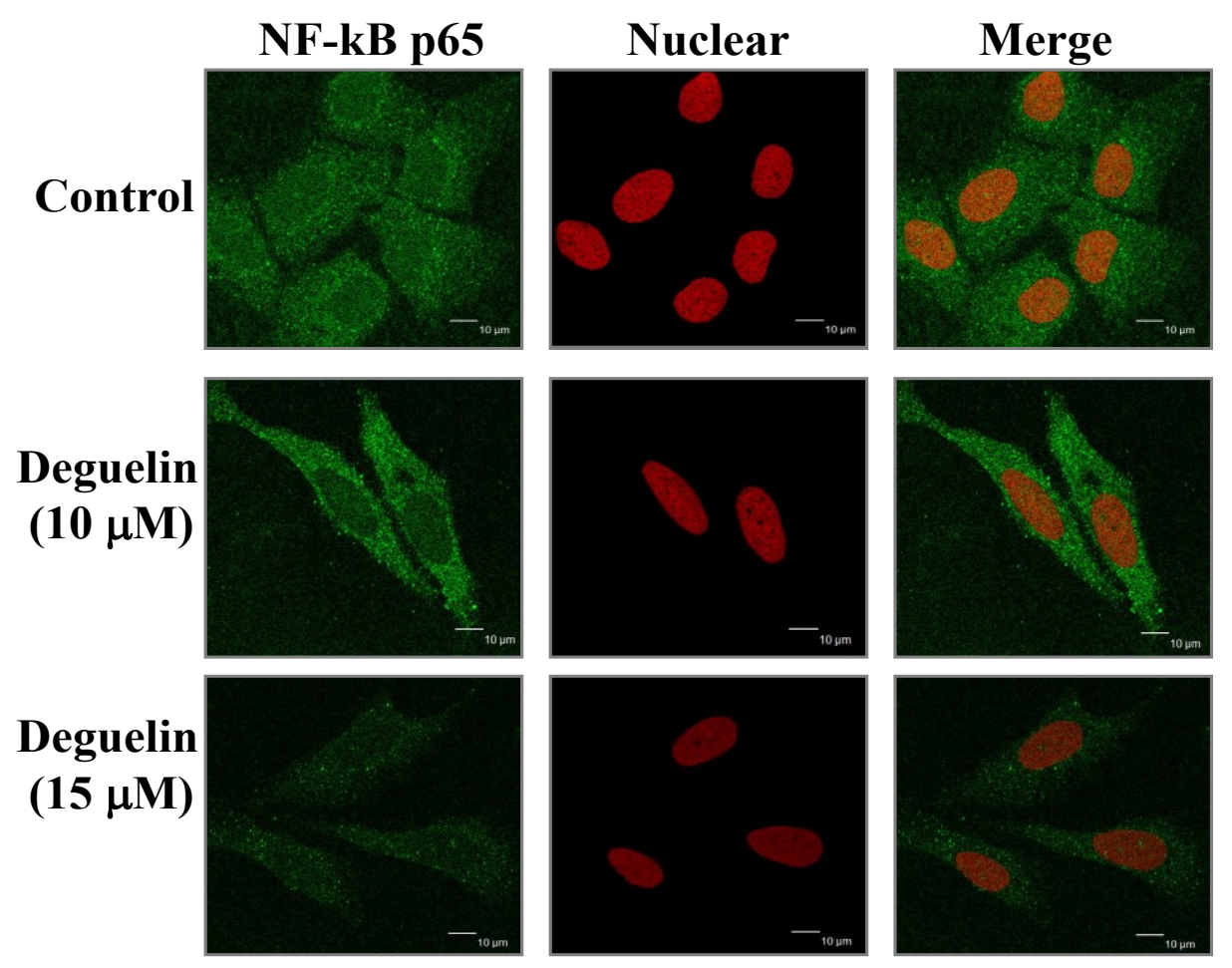

(A)

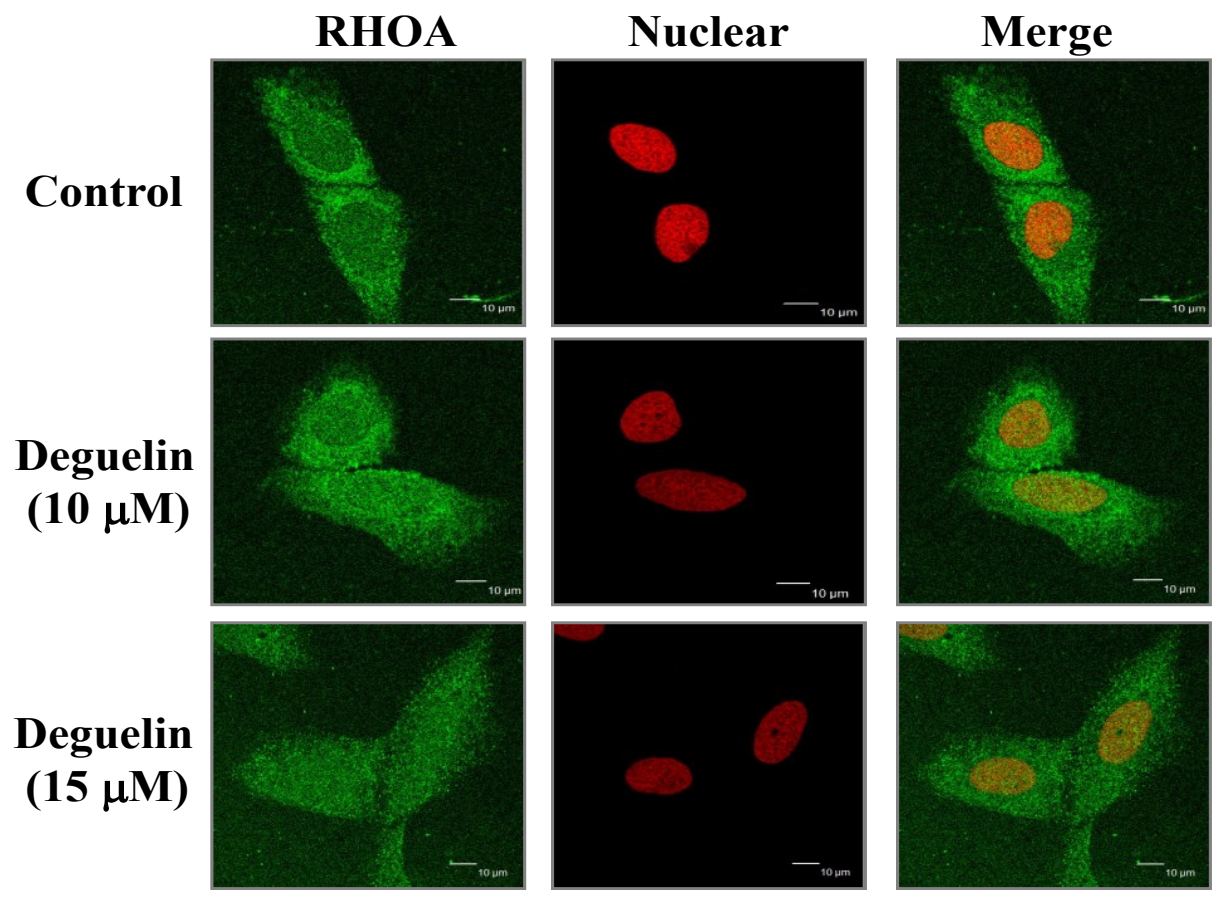

(B) 
Figure 7. Cont.

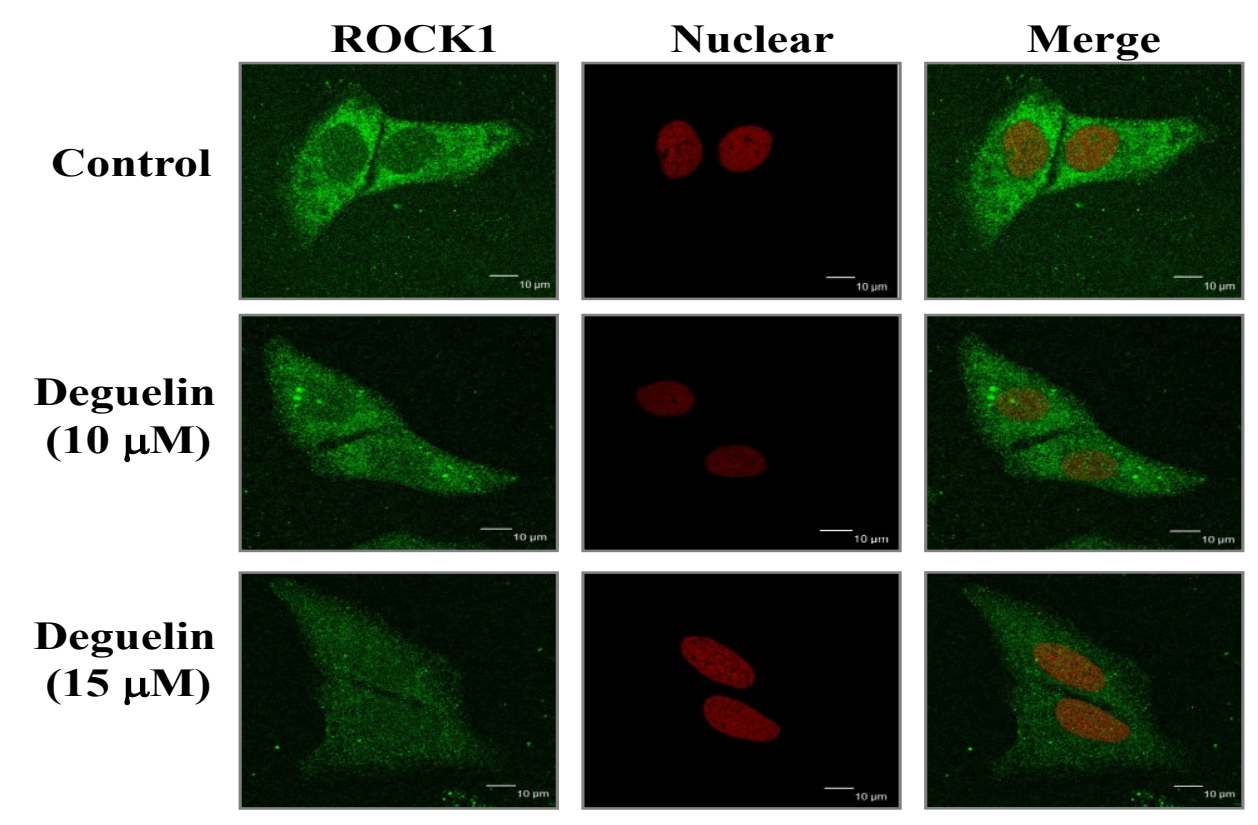

(C)

2.7. Effects of Deguelin on $m R N A$ Expression of MMP-2, MMP-7, MMP-9, Rho A and NF- $k B$ in U-2 OS Cells

In order to investigate whether deguelin affected migration- and invasion-associated gene expression in U-2 OS cells, cells were treated with deguelin $(0$ and $10 \mu \mathrm{M})$ for 0 and $24 \mathrm{~h}$ mRNA expression determined using real time PCR examination. Figure 8 shows that mRNA expression levels of MMP-7 and Rho A mRNA were significantly decreased by deguelin, but levels of MMP-2, MMP-9, NF-кB p65 mRNA were not significantly different.

Figure 8. Real-time PCR of MMP-2, -7, and -9, Rho A and NF- $\kappa$ B. U-2 OS cells were incubated with deguelin $(10 \mu \mathrm{M})$ for $24 \mathrm{~h}$ and then harvested for total RNA extraction for reverse-transcribed RNA samples at $42{ }^{\circ} \mathrm{C}$ with for $30 \mathrm{~min}$. The revised RNA was used for quantitative PCR as described in the Experimental Section. Each assay were performed in triplicate and expression fold-changes were derived using the comparative $\mathrm{C}_{\mathrm{T}}$ method. $* p<0.05$, significant difference between deguelin-treated groups and untreated-groups as analyzed by Student's $t$ test.

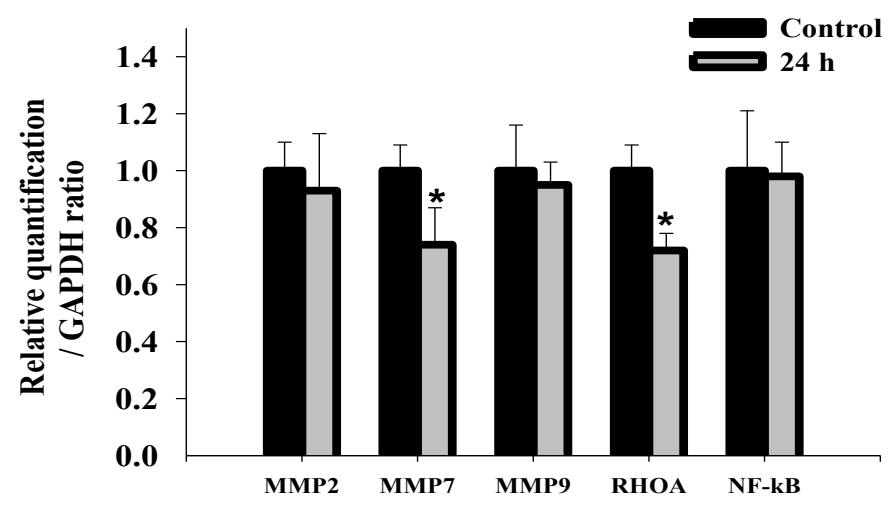




\subsection{Discussion}

Numerous studies showed that deguelin has cytotoxic effects such as the induction of apoptosis by dysregulation of the cell-cycle checkpoint protein in retinoblastoma [25]. In our previous studies, we found deguelin induced DNA damage which was mediated by reducing DNA repair genes in human non-small cell lung cancer NCI-H460 cells [26]. Other reports have shown that deguelin has anti-cancer activity including the prevention of carcinogenesis in animal models of Sprague Dawley rats [17-19]. Cell motility plays an important role in cancer pathology, however, the effects of deguelin on cell motility are not well-understood. In the present study we found that deguelin reduced cell migration (Figures 2 and 3) and invasion (Figure 4) of U-2 OS human osteosarcoma cancer cells in vitro. Effects of deguelin on cell motility were associated with inhibition of MMP-2 and -9 activities in a dose- and time-dependent manner (Figure 5A,B). MMP-2 and -9 are central players in cancer cell migration and invasion [27] and both have been implicated in cancer invasion [1,27].

Herein, we found deguelin reduced protein levels of MMP-2 and -9 and it also decreased the levels of FAK and the down-stream kinases ERK1/2, JNK and p38 in U-2 OS cells (Figure 6A,E,F). $\mathrm{FAK} / \mathrm{Src}$ signaling was found to be involved in tumor metastasis by increasing cell migration and invasiveness [28,29]. Degulein inhibited the migration and invasion of U-2 OS cells may through the inhibition of FAK/src and ERK1/2. It was reported that FAK/Src may act on the down-stream targets PI-3K/AKt and Ras/Erk1/2 [30]. We showed that deguelin decreased protein levels of PI-3K, TIMP1, p-AKT (Ser473) in U-2 OS cells. It has been reported that deguelin acts as an Akt inhibitor by down-regulation of NF- $\mathrm{KB}$ signaling which induced apoptosis in colon cancer cells and inhibited tumor growth in mice [31].

We found that deguelin reduced NF- $\kappa B$ protein levels and decreased NF- $\kappa B$ levels in the cytosol of $\mathrm{U}-2$ OS cells in vitro. It was reported that NF- $\mathrm{KB}$ can affect gene expression of MMP-2 and MMP-9 [32], herein, we suggesting deguelin inhibited MMP-2 and -9 activities which may occur by acting on ERK1/2MAPK and NF- $\kappa B$ signaling pathways. Deguelin inhibited the expression of growth factor receptor-bound protein 2 (GRB2), FAK and Rho A in U2-OS cells that were observed from western blotting (Figure 6). In the present study, the inhibition of GRB2, FAK and Rho A by deguelin may be due to a reduction in levels of MMP-2 and -9 and different lines of evidence support that hypothesis: (1) Rho A protein is associated with metastasis via cyclooxygenase-2 (COX-2) signaling promoting tumor cell motility [33]; and (2) the formation of FAK/Src complex allows Src to phosphorylate FAK and then to mediate its interaction with GRB2 and activate the Ras-ERK signaling pathway [34]. Other reports have demonstrated that angiogenic and metastatic signaling pathways acting through the RAS/RAF/MEK/ERK cascade are involved in the development of hepatocellular carcinoma cells and in the regulation of cell proliferation, apoptosis, cytokine expression and production of MMPs and VEGF in hepatocellular carcinoma (HCC) [35,36]. Deguelin was found to suppress pancreatic tumor growth and metastasis by inhibiting epithelial-to-mesenchymal transition in an orthotopic model [37]. Whether or not such a mechanism occurs in bone osteosarcoma warrants further investigations. 


\section{Experimental Section}

\subsection{Chemicals and Reagents}

Deguelin, dimethyl sulfoxide (DMSO), propidium iodide (PI), Tris-HCl Trypsin, and Trypan blue were obtained from Sigma Chemical Co. (St. Louis, MO, USA). McCoy's 5A medium with L-glutamine, fetal bovine serum, penicillin-streptomycin, and trypsin-EDTA were obtained from Gibco BRL (Grand Island, NY, USA). All chemicals and reagents were of analytical grade.

\subsection{U-2 OS Cell Culture}

The U-2 OS human osteosarcoma cell line was obtained from the Food Industry Research and Development Institute (Hsinchu, Taiwan) and kept frozen under liquid nitrogen in 10\% DMSO with fetal bovine serum until use. U-2 OS cells were quickly thawed and maintained in 90\% McCoy's 5A medium with $10 \%$ FBS, $2 \mathrm{mM}$ L-glutamine, $100 \mathrm{Units} / \mathrm{mL}$ penicillin and $100 \mu \mathrm{g} / \mathrm{mL}$ streptomycin and plated onto $75 \mathrm{~cm}^{2}$ tissue culture flasks at $37{ }^{\circ} \mathrm{C}$ under a humidified $5 \% \mathrm{CO}_{2}$ atmosphere as described previously $[38,39]$.

\subsection{Cell Viability Assay}

U-2 OS cells were seeded onto 12-well plates at a density of $2 \times 10^{5}$ cells/well and treated with deguelin $(0,5,10,15$ and $20 \mu \mathrm{M})$ or $0.5 \%$ DMSO (as a vehicle control) for 24 and $48 \mathrm{~h}$. At the end of the incubation period, cells were harvested and stained with $5 \mu \mathrm{g} / \mathrm{mL}$ of PI and then were analyzed using a PI exclusion method by flow cytometry (BD Biosciences, FACS Calibur, San Jose, CA, USA) as previously described [38,39].

\subsection{Scratch Wound Healing Assay}

U-2 OS cells at a density of $5 \times 10^{5}$ cells/well were cultured in 6-well plates with serum-free McCoy's $5 \mathrm{~A}$ medium until they were $100 \%$ confluent in an adherent monolayer. A sterile yellow $10 \mu \mathrm{L}$ Eppendorf tip was used to scratch the cells in the plate and then washed with PBS three times. The cells were then placed in fresh serum-free McCoy's 5A medium containing 0, 10 and $15 \mu \mathrm{M}$ of deguelin for $0,12,24 \mathrm{~h}$ then random fields were examined, selected and photographed with an inverted microscope as described previously [40,41].

\subsection{Cell Invasion and Migration Assays in Vitro}

Cell migration and invasion assays were conducted using the Matrigel Cell Migration Assay and Invasion System as described previously [42,43]. The Migration assay for cell migration was conducted using transwell (BD Biosciences, Franklin Lakes, NJ, USA) cell culture chambers (8 mm pore size; Millipore, Billerica, MA, USA). U-2 OS cells were maintained in serum-free McCoy's 5A medium for $24 \mathrm{~h}$. Cells were then trypsinized and resuspended in serum-free McCoy's 5A medium, and cells at $5 \times 10^{4}$ cells/well were placed in the upper chamber of the transwell insert and incubated with $0.5 \%$ DMSO or deguelin $(10$ and $15 \mu \mathrm{M})$, and 90\% McCoy's 5A medium containing 10\% FBS was added to the lower chamber and incubated for 24 or $48 \mathrm{~h}$. In the upper chamber, cells remaining 
were removed by wiping with a sterile cotton swab and in the lower surface of the filter, the migrated cells were fixed with $4 \%$ formaldehyde in PBS and stained with $2 \%$ crystal violet in $2 \%$ ethanol and then were counted and photographed with a light microscope at $200 \times$. The cell invasion assay was performed as described except that the filter membrane was coated with Matrigel from a BioCoat Matrigel invasion kit (Becton Dickinson Bioscience, Bedford, MA, USA). Cells located on the underside of the filter were counted and photographed with a light microscope at $200 \times$. The invasive cells were expressed as the mean number of cells (mean \pm SD of cells) on the lower side of the filter. The assay was done in triplicate. The experiment was repeated three times.

\subsection{Gelatin Gel Zymographic Assay for MMP Activity}

U-2 OS cells at a density of $5 \times 10^{5}$ cells/well were plated in 12-well plates for $24 \mathrm{~h}$. Deguelin $(0,2.5,5,10,15$ and $20 \mu \mathrm{M})$ was then added to well and cells were then incubated at $37{ }^{\circ} \mathrm{C}$ for 24 and $48 \mathrm{~h}$. At the end of the incubation periods, the supernatant from each concentrated culture was re-suspended in non reducing loading buffer and incubated at $37{ }^{\circ} \mathrm{C}$ for $15 \mathrm{~min}$. Each sample was prepared in $10 \%$ SDS-PAGE cast with $0.1 \%$ gelatin and then electrophoresed. After electrophoresis, gels were washed successively with $50 \mathrm{~mL}$ of $2.5 \%(\mathrm{v} / \mathrm{v})$ Triton X-100 in distilled water twice $(30 \mathrm{~min}$ each) and 2.5\% (v/v) Triton X-100 in Tris buffer twice (30 min each) to remove SDS. Gels were then incubated in a developing buffer (50 mM Tris- $\left.\mathrm{HCl}(\mathrm{pH} 7.8) 10 \mathrm{mM} \mathrm{CaCl}_{2}, 150 \mathrm{mM} \mathrm{NaCl}\right)$ for $16 \mathrm{~h}$ at $37^{\circ} \mathrm{C}$. Gels were then stained with Coomassie Brilliant Blue R 250 and destained with $30 \%$ methanol, $10 \%$ acetic acid in order to reveal zones of substrate lysis for detecting gelatinase secretion [44]. In the blue backgroung gel, the gelatinolytic activity was visualized as clear zones and the intensity was measured using Quantity One software as described previously [44].

\subsection{Immunofluorescence Staining and Confocal Laser Scanning Microscopy}

U-2 OS cells at a density of $5 \times 10^{5}$ cells/well were plated on 4-well chamber slides before being treated with 0,10 and $15 \mu \mathrm{M}$ of deguelin for $24 \mathrm{~h}$. Cells were then fixed in 3\% formaldehyde in PBS for 15 min. Triton X-100 (0.1\%) in PBS was used to permeabilize cells for $1 \mathrm{~h}$ with blocking of U-2 OS cells at a density of $5 \times 10^{5}$ cells/well and were placed in n-specific binding sites using $2 \%$ BSA as described previously (A, B). After the fixation, cells on the slides were stained with anti-NF-kB, Rho A and ROCK1 (1:200 dilution) as primary antibodies overnight and then were stained with FITC-conjugated goat anti-mouse IgG at 1:200 dilution) (green fluorescence) as a secondary antibody. The mitochondria and nuclei were counterstained individually with MitoTracker ${ }^{\circledR}$ Red CMXRos and PI (Molecular Probes/Invitrogen Corp., Carlsbad, CA, USA) (red fluorescence). All samples were photomicrographed with a Leica TCS SP2 confocal spectral microscope as described previously [27,28].

\subsection{Western Blotting Analysis}

$\mathrm{U}-2$ OS cells at a density of $1 \times 10^{6}$ cells/well were plated on 6-well plates for $24 \mathrm{~h}$. Deguelin (10 and $15 \mu \mathrm{M}$ ) was added to wells while DMSO (solvent control) was added to control cells and incubated at $37{ }^{\circ} \mathrm{C}$ for 24 and $48 \mathrm{~h}$. Cells were then harvested and lysed with ice-cold $50 \mathrm{mM}$ potassium phosphate buffer ( $\mathrm{pH} 7.4$ ) containing 2 mM EDTA and $0.1 \%$ Triton X-100. Cells were then 
homogenized in a Dounce homogenizer with optimal gentle strokes followed by centrifugation at 13,000 rpm for $10 \mathrm{~min}$ at $4{ }^{\circ} \mathrm{C}$. The supernatant was collected as the cytosolic proteins and total protein was determined using a Bio-Rad protein assay kit (Hercules, CA, USA) with bovine serum albumin (BSA) as the standard. Equal amounts of proteins from each sample were separated on 10\% SDS-polyacrylamide gels, followed by electrophoretic transfer to PVDF (polyvinylidene fluoride, Millipore, Bedford, MA, USA) membranes. The membranes were blotted with the relevant primary antibodies, washed and then were stained with a secondary antibody and protein bands were detected with an enhanced chemiluminescent substrate (ECLTM, Amersham Biosciences, Amersham, UK). Bands were quantified using NIH Image analyzer software (NIH, Bethesda, MD, USA) [42,44].

\subsection{Real-time PCR of MMP-2, -7, and -9, Rho A and NF-kB}

U2-OS cells $\left(1 \times 10^{6}\right.$ cells/well) were plated in 6-well plates for $24 \mathrm{~h}$ and then were incubated with deguelin $(10 \mu \mathrm{M})$ for $24 \mathrm{~h}$ and then harvested for total RNA extraction using the Qiagen RNeasy Mini Kit as described previously [18-21]. High Capacity cDNA Reverse Transcription Kit was used for reverse-transcribed RNA samples at $42{ }^{\circ} \mathrm{C}$ for $30 \mathrm{~min}$ according to the protocol of the supplier (Applied Biosystems, Carlsbad, CA, USA). The revised cDNA was used for quantitative PCR and the conditions were: $2 \mathrm{~min}$ at $50{ }^{\circ} \mathrm{C}, 10 \mathrm{~min}$ at $95{ }^{\circ} \mathrm{C}$, and 40 cycles of $15 \mathrm{~s}$ at $95{ }^{\circ} \mathrm{C}$; 1 min at $60{ }^{\circ} \mathrm{C}$ using $10 \mathrm{ng} / \mu \mathrm{L}$ of the cDNA reverse-transcribed as described above, $2 \mathrm{X}$ SYBR Green PCR Master Mix (Applied Biosystems) and $200 \mathrm{nM}$ of forward and reverse primers as shown in Table 1 as described previously [18-21]. Each assay were performed using an Applied Biosystems 7300 Real-Time PCR system in triplicate and expression fold-changes were calculated using the comparative $\mathrm{C}_{\mathrm{T}}$ method [45-48].

Table 1. The DNA sequence was evaluated using the Primer Expression.

\begin{tabular}{cc}
\hline Primer Name & Primer Sequence \\
\hline homo MMP-2-F & CCCCAGACAGGTGATCTTGAC \\
homo MMP-2-R & GCTTGCGAGGGAAGAAGTTG \\
homo MMP-7-F & GGATGGTAGCAGTCTAGGGATTAACT \\
homo MMP-7-R & AGGTTGGATACATCACTGCATTAGG \\
homo MMP-9-F & CGCTGGGCTTAGATCATTCC \\
homo MMP-9-R & AGGTTGGATACATCACTGCATTAGG \\
homo NF-kB-F & AGTTGAGGGGACTTTCCCAGGC \\
homo NF-kB-R & TCAACTCCCCTGAAAGGGTCCG \\
homo RhoA-F & TCAAGCCGGAGGTCAACAAC \\
homo RhoA-R & ACGAGCTGCCCATAGCAGAA \\
Homo GAPDH-F & ACACCCACTCCTCCACCTTT \\
Homo GAPDH-R & TAGCCAAATTCGTTGTCATACC \\
\hline
\end{tabular}

MMP, Matrix metalloproteinase; NF- $\mathrm{B}$, nuclear factor-kappaB; RhoA, RAS homologue gene family member A; ROCK1, Rho-associated coiled coil-containing kinase; GAPDH, Glyceraldehyde-3-phosphate dehydrogenase; F, forward primers; $\mathrm{R}$, reverse primers. 


\subsection{Statistical Analysis}

All results were done in 3 independent experiments and expressed as mean \pm SD. Differences between the deguelin-treated and control groups were analyzed by Student's $t$ test, with values of $* p<0.05$ considered significant.

\section{Conclusions}

In conclusion, we show for the first time that deguelin inhibits cancer cell migration and invasion in U-2 OS cancer cells. Several different signaling pathways may be involved in these inhibitor actions which are depicted in Figure 9. Numerous studies have shown deguelin induced cytotoxic effects in human cancer cells $[26,31,49,50]$. Herein, we propose that deguelin may have potential as a novel anti-cancer agent for the treatment of osteosarcoma by inhibition of migration and invasion and provides the rationale for in vivo studies in animal models.

Figure 9. The possible signaling pathways for deguelin inhibited cell invasion and migration in U-2 OS human osteosacroma cells.

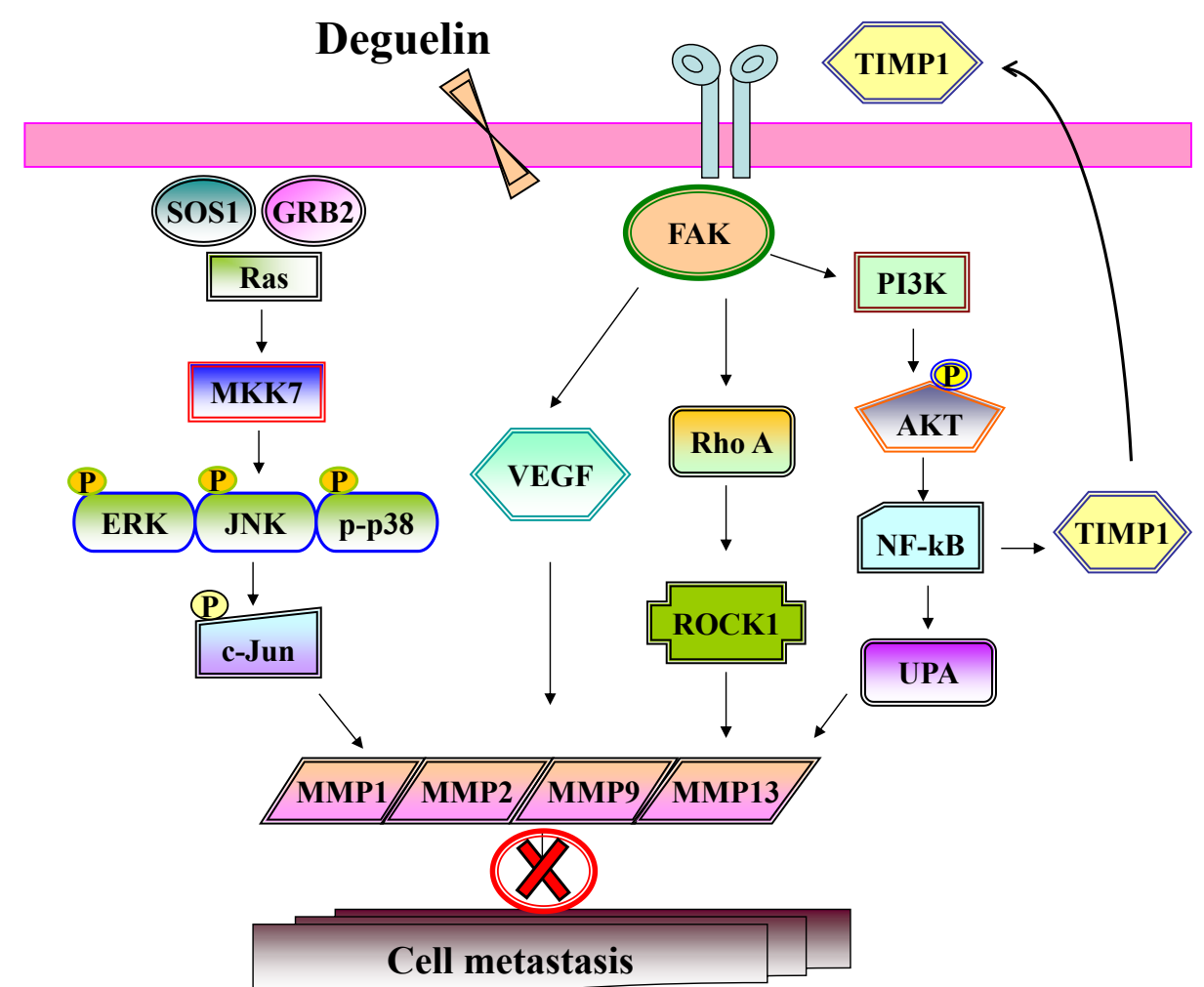

\section{Acknowledgments}

This work was supported by grant DOH101-TD-C-111-005 from Department of Health, Executive Yuan, R.O.C (Taiwan). Experiments and data analysis were performed in part through the use of the Medical Research Core Facilities Center, Office of Research \& Development at China medical University, Taichung, Taiwan, R.O.C. 


\section{Author Contributions}

H.-S.S., J.-P.L. and J.-G.C. conceived and designed the study. J.-B.C., J.-H.L., S.-C.H. and C.-M.L. performed the experiments. J.-G.C. and J.-P.L. wrote the paper. J.-Y.L., P.-P.W., M.-K.A. and H.-F.L. reviewed and edited the manuscript. All authors read and approved the manuscript.

\section{Conflicts of Interest}

The authors declare that there are no conflicts of interest.

\section{References}

1. Sangle, N.A.; Layfield, L.J. Telangiectatic osteosarcoma. Arch. Pathol. Lab. Med. 2012, 136, $572-576$.

2. Huh, W.W.; Holsinger, F.C.; Levy, A.; Palla, F.S.; Anderson, P.M. Osteosarcoma of the jaw in children and young adults. Head Neck 2012, 34, 981-984.

3. Kaste, S.C. Imaging pediatric bone sarcomas. Radiol. Clin. North Am. 2011, 49, 749-765.

4. Thayanithy, V.; Park, C.; Sarver, A.L.; Kartha, R.V.; Korpela, D.M.; Graef, A.J.; Steer, C.J.; Modiano, J.F.; Subramanian, S. Combinatorial treatment of DNA and chromatin-modifying drugs cause cell death in human and canine osteosarcoma cell lines. PLoS One 2012, 7, e43720.

5. Fuchs, B.; Pritchard, D.J. Etiology of osteosarcoma. Clin. Orthop. Relat. Res. 2002, 397, 40-52.

6. Marina, N.; Gebhardt, M.; Teot, L.; Gorlick, R. Biology and therapeutic advances for pediatric osteosarcoma. Oncologist 2004, 9, 422-441.

7. Geller, D.S.; Gorlick, R. Osteosarcoma: A review of diagnosis, management, and treatment strategies. Clin. Adv. Hematol. Oncol. 2010, 8, 705-718.

8. Olson, M.F. Follow the leader: LIM kinases pave the way for collective tumor cell invasion. Cell Cycle 2010, 9, 4417-4418.

9. Thompson, L.; Wang, S.; Tawfik, O.; Templeton, K.; Tancabelic, J.; Pinson, D.; Anderson, H.C.; Keighley, J.; Garimella, R. Effect of 25-hydroxyvitamin D3 and 1 alpha,25 dihydroxyvitamin D3 on differentiation and apoptosis of human osteosarcoma cell lines. J. Orthop. Res. 2012, 30, 831-844.

10. Benayahu, D.; Shur, I.; Marom, R.; Meller, I.; Issakov, J. Cellular and molecular properties associated with osteosarcoma cells. J. Cell. Biochem. 2001, 84, 108-114.

11. Campbell, P.G.; Wines, K.; Yanosick, T.B.; Novak, J.F. Binding and activation of plasminogen on the surface of osteosarcoma cells. J. Cell. Physiol. 1994, 159, 1-10.

12. Smeds, S.; Walz, T.; Blomquist, L.; Larsson, S.E. Cell proliferation rate and tumor volume in human osteosarcoma during exposure to methotrexate. A study on tissue transplants in nude mice. APMIS 1991, 99, 898-904.

13. Tingting, R.; Wei, G.; Changliang, P.; Xinchang, L.; Yi, Y. Arsenic trioxide inhibits osteosarcoma cell invasiveness via MAPK signaling pathway. Cancer Biol. Ther. 2010, 10, 251-257.

14. Sun, D.; Wang, X.; Zhang, H.; Deng, L.; Zhang, Y. MMP9 mediates MICA shedding in human osteosarcomas. Cell Biol. Int. 2011, 35, 569-574. 
15. Berge, G.; Pettersen, S.; Grotterod, I.; Bettum, I.J.; Boye, K.; Maelandsmo, G.M. Osteopontin-An important downstream effector of S100A4-mediated invasion and metastasis. Int. J. Cancer. 2011, 129, 780-790.

16. Korpi, J.T.; Hagstrom, J.; Lehtonen, N.; Parkkinen, J.; Sorsa, T.; Salo, T.; Laitinen, M. Expression of matrix metalloproteinases-2, $-8,-13,-26$, and tissue inhibitors of metalloproteinase-1 in human osteosarcoma. Surg. Oncol. 2011, 20, e18-e22.

17. Lee, H.Y.; Oh, S.H.; Woo, J.K.; Kim, W.Y.; van Pelt, C.S.; Price, R.E.; Cody, D.; Tran, H.; Pezzuto, J.M.; Moriarty, R.M.; et al. Chemopreventive effects of deguelin, a novel Akt inhibitor, on tobacco-induced lung tumorigenesis. J. Natl. Cancer Inst. 2005, 97, 1695-1699.

18. Udeani, G.O.; Gerhauser, C.; Thomas, C.F.; Moon, R.C.; Kosmeder, J.W.; Kinghorn, A.D.; Moriarty, R.M.; Pezzuto, J.M. Cancer chemopreventive activity mediated by deguelin, a naturally occurring rotenoid. Cancer Res. 1997, 57, 3424-3428.

19. Gerhauser, C.; Lee, S.K.; Kosmeder, J.W.; Moriarty, R.M.; Hamel, E.; Mehta, R.G.; Moon, R.C.; Pezzuto, J.M. Regulation of ornithine decarboxylase induction by deguelin, a natural product cancer chemopreventive agent. Cancer Res. 1997, 57, 3429-3435.

20. Murillo, G.; Kosmeder, J.W.; Pezzuto, J.M.; Mehta, R.G. Deguelin suppresses the formation of carcinogen-induced aberrant crypt foci in the colon of CF-1 mice. Int. J. Cancer 2003, 104, $7-11$.

21. Gerhauser, C.; Mar, W.; Lee, S.K.; Suh, N.; Luo, Y.; Kosmeder, J.; Luyengi, L.; Fong, H.H.; Kinghorn, A.D.; Moriarty, R.M.; et al. Rotenoids mediate potent cancer chemopreventive activity through transcriptional regulation of ornithine decarboxylase. Nat. Med. 1995, 1, 260-266.

22. Yan, Y.; Wang, Y.; Tan, Q.; Lubet, R.A.; You, M. Efficacy of deguelin and silibinin on benzo(a)pyrene-induced lung tumorigenesis in A/J mice. Neoplasia 2005, 7, 1053-1057.

23. Lee, H.Y.; Suh, Y.A.; Kosmeder, J.W.; Pezzuto, J.M.; Hong, W.K.; Kurie, J.M. Deguelin-induced inhibition of cyclooxygenase-2 expression in human bronchial epithelial cells. Clin. Cancer Res. 2004, 10, 1074-1079.

24. Nair, A.S.; Shishodia, S.; Ahn, K.S.; Kunnumakkara, A.B.; Sethi, G.; Aggarwal, B.B. Deguelin, an Akt inhibitor, suppresses IkappaBalpha kinase activation leading to suppression of NF-kappaB-regulated gene expression, potentiation of apoptosis, and inhibition of cellular invasion. J. Immunol. 2006, 177, 5612-5622.

25. Murillo, G.; Salti, G.I.; Kosmeder, J.W.; Pezzuto, J.M.; Mehta, R.G. Deguelin inhibits the growth of colon cancer cells through the induction of apoptosis and cell cycle arrest. Eur. J. Cancer 2002, $38,2446-2454$.

26. Ji, B.C.; Yu, C.C.; Yang, S.T.; Hsia, T.C.; Yang, J.S.; Lai, K.C.; Ko, Y.C.; Lin, J.J.; Lai, T.Y.; Chung, J.G. Induction of DNA damage by deguelin is mediated through reducing DNA repair genes in human non-small cell lung cancer NCI-H460 cells. Oncol. Rep. 2012, 27, 959-964.

27. Toth, M.; Sohail, A.; Fridman, R. Assessment of gelatinases (MMP-2 and MMP-9) by gelatin zymography. Methods Mol. Biol. 2012, 878, 121-135.

28. Bianchi-Smiraglia, A.; Paesante, S.; Bakin, A.V. Integrin beta5 contributes to the tumorigenic potential of breast cancer cells through the Src-FAK and MEK-ERK signaling pathways. Oncogene 2012, 32, 3049-3058. 
29. Shen, J.; Xu, L.; Owonikoko, T.K.; Sun, S.Y.; Khuri, F.R.; Curran, W.J.; Deng, X. NNK promotes migration and invasion of lung cancer cells through activation of c-Src/PKCiota/FAK loop. Cancer Lett. 2012, 318, 106-113.

30. Oktay, M.; Wary, K.K.; Dans, M.; Birge, R.B.; Giancotti, F.G. Integrin-mediated activation of focal adhesion kinase is required for signaling to Jun NH2-terminal kinase and progression through the G1 phase of the cell cycle. J. Cell Biol. 1999, 145, 1461-1469.

31. Kang, H.W.; Kim, J.M.; Cha, M.Y.; Jung, H.C.; Song, I.S.; Kim, J.S. Deguelin, an Akt inhibitor, down-regulates NF-kappaB signaling and induces apoptosis in colon cancer cells and inhibits tumor growth in mice. Dig. Dis. Sci. 2012, 57, 2873-2882.

32. Li, Q.; Verma, I.M. NF-kappaB regulation in the immune system. Nat. Rev. Immunol. 2002, 2, $725-734$.

33. Chang, Y.W.; Marlin, J.W.; Chance, T.W.; Jakobi, R. RhoA mediates cyclooxygenase-2 signaling to disrupt the formation of adherens junctions and increase cell motility. Cancer Res. 2006, 66, 11700-11708.

34. Sanders, M.A.; Basson, M.D. Collagen IV regulates Caco-2 migration and ERK activation via alphalbeta1- and alpha2betal-integrin-dependent Src kinase activation. Am. J. Physiol. Gastrointest. Liver Physiol. 2004, 286, G547-557.

35. Wiedmann, M.W.; Mossner, J. Molecular targeted therapy of hepatocellular carcinoma-Results of the first clinical studies. Curr. Cancer Drug Targets 2011, 11, 714-733.

36. Mayoral, R.; Fernandez-Martinez, A.; Bosca, L.; Martin-Sanz, P. Prostaglandin E2 promotes migration and adhesion in hepatocellular carcinoma cells. Carcinogenesis 2005, 26, 753-761.

37. Boreddy, S.R.; Srivastava, S.K. Deguelin suppresses pancreatic tumor growth and metastasis by inhibiting epithelial-to-mesenchymal transition in an orthotopic model. Oncogene 2012, 32, 3980-3991.

38. Chiu, Y.J.; Hour, M.J.; Lu, C.C.; Chung, J.G.; Kuo, S.C.; Huang, W.W.; Chen, H.J.; Jin, Y.A.; Yang, J.S. Novel quinazoline HMJ-30 induces U-2 OS human osteogenic sarcoma cell apoptosis through induction of oxidative stress and up-regulation of ATM/p53 signaling pathway. J. Orthop. Res. 2011, 29, 1448-1456.

39. Huang, W.W.; Chiu, Y.J.; Fan, M.J.; Lu, H.F.; Yeh, H.F.; Li, K.H.; Chen, P.Y.; Chung, J.G.; Yang, J.S. Kaempferol induced apoptosis via endoplasmic reticulum stress and mitochondria-dependent pathway in human osteosarcoma U-2 OS cells. Mol. Nutr. Food Res. 2010, 54, 1585-1595.

40. Chueh, F.S.; Chen, Y.Y.; Huang, A.C.; Ho, H.C.; Liao, C.L.; Yang, J.S.; Kuo, C.L.; Chung, J.G. Bufalin-inhibited migration and invasion in human osteosarcoma U-2 OS cells is carried out by suppression of the matrix metalloproteinase-2, ERK, and JNK signaling pathways. Environ. Toxicol. 2011, 29, 21-29.

41. Chen, K.T.; Hour, M.J.; Tsai, S.C.; Chung, J.G.; Kuo, S.C.; Lu, C.C.; Chiu, Y.J.; Chuang, Y.H.; Yang, J.S. The novel synthesized 6-fluoro-(3-fluorophenyl)-4-(3-methoxyanilino)quinazoline (LJJ-10) compound exhibits anti-metastatic effects in human osteosarcoma U-2 OS cells through targeting insulin-like growth factor-I receptor. Int. J. Oncol. 2011, 39, 611-619. 
42. Kwon, S.H.; Park, H.Y.; Kim, J.Y.; Jeong, I.Y.; Lee, M.K.; Seo, K.I. Apoptotic action of ursolic acid isolated from Corni fructus in RC-58T/h/SA\#4 primary human prostate cancer cells. Bioorg. Med. Chem. Lett. 2010, 20, 6435-6438.

43. Wang, M.Y.; Zhao, F.M.; Peng, H.Y.; Lou, C.H.; Li, Y.; Ding, X.; Yu, X.Y.; Yang, G.M.; $\mathrm{Xu}$, D.Q.; Jiang, L.H.; et al. Investigation on the morphological protective effect of 5-hydroxymethylfurfural extracted from wine-processed Fructus corni on human L02 hepatocytes. J. Ethnopharmacol. 2010, 130, 424-428.

44. Liao, C.L.; Lai, K.C.; Huang, A.C.; Yang, J.S.; Lin, J.J.; Wu, S.H.; Gibson Wood, W.; Lin, J.G.; Chung, J.G. Gallic acid inhibits migration and invasion in human osteosarcoma U-2 OS cells through suppressing the matrix metalloproteinase-2/-9, protein kinase B (PKB) and PKC signaling pathways. Food Chem. Toxicol. 2012, 50, 1734-1740.

45. Pilcher, B.K.; Dumin, J.A.; Sudbeck, B.D.; Krane, S.M.; Welgus, H.G.; Parks, W.C. The activity of collagenase-1 is required for keratinocyte migration on a type I collagen matrix. J. Cell Biol. 1997, 137, 1445-1457.

46. Fishman, D.A.; Liu, Y.; Ellerbroek, S.M.; Stack, M.S. Lysophosphatidic acid promotes matrix metalloproteinase (MMP) activation and MMP-dependent invasion in ovarian cancer cells. Cancer Res. 2001, 61, 3194-3199.

47. Huang, Y.T.; Hwang, J.J.; Lee, L.T.; Liebow, C.; Lee, P.P.; Ke, F.C.; Lo, T.B.; Schally, A.V.; Lee, M.T. Inhibitory effects of a luteinizing hormone-releasing hormone agonist on basal and epidermal growth factor-induced cell proliferation and metastasis-associated properties in human epidermoid carcinoma A431 cells. Int. J. Cancer 2002, 99, 505-513.

48. Hsu, S.C.; Kuo, C.L.; Lin, J.P.; Lee, J.H.; Lin, C.C.; Su, C.C.; Yang, M.D.; Chung, J.G. Crude extracts of Euchresta formosana radix inhibit invasion and migration of human hepatocellular carcinoma cells. Anticancer Res. 2007, 27, 2377-2384.

49. Yang, Y.L.; Ji, C.; Bi, Z.G.; Lu, C.C.; Wang, R.; Gu, B.; Cheng, L. Deguelin induces both apoptosis and autophagy in cultured head and neck squamous cell carcinoma cells. PLoS One 2013, 8, e54736.

50. Mehta, R.; Katta, H.; Alimirah, F.; Patel, R.; Murillo, G.; Peng, X.; Muzzio, M.; Mehta, R.G. Deguelin action involves c-Met and EGFR signaling pathways in triple negative breast cancer cells. PLoS One 2013, 8, e65113.

Sample Availability: Samples of the deguelin are not available.

(C) 2014 by the authors; licensee MDPI, Basel, Switzerland. This article is an open access article distributed under the terms and conditions of the Creative Commons Attribution license (http://creativecommons.org/licenses/by/4.0/). 